\title{
POLA KOMUNIKASI RITUAL ORANG TUA-ANAK DALAM PEWARISAN PENGETAHUAN DAN AFEKSI TERKAIT PEKERJAAN DI SEKTOR PERTANIAN PADI
}

(Kasus Pemuda di Desa Ciasmara Kecamatan Pamijahan Kabupaten Bogor)

\author{
Yogaprasta Adi Nugraha ${ }^{1}$, R Atang Supriatna ${ }^{2}$ \\ 1,2 FISIB, Universitas Pakuan \\ yogaprasta_adinugraha@yahoo.com
}

Diterima : 05 Desember 2019; Review : 0g Februari 2020; Direvisi Author : 08 Februari 2020; Terbit : 14 Februari 2020

\begin{abstract}
Agriculture is one of potential sector that contribute positevely to national income. But Paradoxicaly, the importance of agricutural sector is not followed by their workers regeneration. Rural youth is prefer to go from agricultural work due to several justification such as land conversion, less-benefit, unprestige work, and negative construction by the social system. This research has several problem statements, namely: (1) What kind of ritual practice in agricultural sector that commonly happend in the village? (2) What kind of rural-youth involvement in helping their parents in agricultural work? (3) Is there any correlation between rural-youth involvement and rural-youth cognitive and affective toward agricultural work? The objectives of this research are: (1) Identifying the ritual practice in agriculture sector, (2) Identifying the rural-youth involvement in helping their parents in agricultural work, (3) Analyzing corelation between rural youth involvement and rural youth cognitive and affective towards agriculture work. The main hypotheses in this research is trying to prove that rural-youth involement in helping their parents in agricultural work will increase rural youth cognitive and affective toward agricultural work. Mixed Method Concurrent was used as research method, taken place in Ciasmara Village from March 2019 to August 2019, 129 youth were taken as research sample by using purposive sampling. This research found that ritual of Sedekah Bumi still exist in Ciasmara Village, rural - youth still involve in helping their parents in agriculture sector, mostly in harvesting period. Rural youth involvement in agriculture sector correlated to rural - youth cognitive and affentive.
\end{abstract}

Keywords: Agriculture involvement, cognitive and affective level, rural youth,

\section{PENDAHULUAN}

Pertanian merupakan salah satu sektor unggulan yang berkontribusi sebesar 15,3 persen pada Produk Domestik Bruto (PDB) Indonesia pada tahun 2009. Pertimbangan lain yang menguatkan bahwa sektor pertanian menjadi sektor unggulan di Indonesia ketika ekspor produk non-pertanian mengalami penurunan, ekspor produk pertanian justru mengalami peningkatan tajam (Nugraha, 2012). Berdasarkan BPS 20187 Sektor pertanian merupakan salah satu sektor penting dalam menggerakan roda perekonomi nasional. Berdasarkan catatan Badan Pusat Statistik (BPS), pada triwulan II 2017, sektor pertanian terus memberi kontribusi positif untuk perekonomian Indonesia. Menurut BPS, terlihat bahwa besaran produk domestik 


\section{Commed : Jurnal Komunikasi dan Media Vol. 4 No. 2 Februari 2020}

ISSN. 2527-8673

E-ISSN. 2615.6725

bruto (PDB) Indonesia mencapai Rp 3.366,8

triliun. Jika dilihat dari sisi produksi, Sektor pertanian merupakan sektor kedua paling berpengaruh terhadap pertumbuhan ekonomi, setelah industri pengolahan. Selain kontribusinya yang tinggi terhadap PDB, sektor pertanian juga memegang peranan penting sebagai penyedia pangan Nasional. Namun, ironi terbesar dari sektor pertanian adalah rendahnya regenerasi pemuda bekerja di sektor pertanian. Kondisi ini memunculkan kekhawatiran tersendiri karena dapat berdampak terhadap stabilitas pangan nasional. Beberapa studi telah mengidentifikasi faktor utama pemuda desa, berikut beberapa faktor antara lain: (1) Tingginya konversi lahan dari lahan pertanian ke lahan non pertanian sehingga aksesibilitas logis terhadap tanah menjadi sangat terbatas. (2) Secara ekonomi, pemuda menganggap sektor pertanian kurang menguntungkan, meskipun tidak selalu demikian. (3) Sistem sosial sekitar pemuda yang cenderung menkonstruksi nilai pertanian secara negatif. (4) Pertanian dianggap tidak bergengsi oleh pemuda di desa (Nugraha 2012; Nugraha dan Herawati, 2015; Valdiani et al, 2017). Partisipasi pemuda dalam sektor pertanian akan sangat dipengaruhi oleh sikap mereka terhadap pekerjaan di sektor pertanian. Sikap pemuda sendiri tidak bisa terlepas dari aktor aktor utama pembentukan sikap, yaitu orang tua, teman, media massa, dan sistem pendidikan sekolah. Penelitian ini fokus kepada peran orang tua, terutama berkaitan dengan pelibatan pemuda dalam kegiatan bertani, dalam membentuk sikap pemuda terhadap pekerjaan di sektor pertanian.

Sebagai negara agraris yang meletakan pembangunan perekonomian pada pertanian, dalam jangka pendek maupun jangka panjang fenomena rendahnya minat pemuda akan membawa konsekuensi tersendiri. Kelangkaan sumberdaya manusia di sektor pertanian atau keterlibatan sebagian besar tenaga kerja pertanian yang setengah terpaksa akibat tidak terbukanya alternatif lain, mengakibatkan proses produksi tidak optimal. Produktivitas tenaga kerja mengalami hal yang sama. Hal ini akan menghambat perkembangan pembangunan itu sendiri, tetapi masih terdapat pula pemuda yang berasal dari keluarga pertanian yang tetap bekerja di bidang pertanian dan tidak memilih bidang di luar sektor pertanian. Artinya terdapat perbedaan sikap pemuda dalam memandang sektor pertanian sebagai pekerjaan masa depan. Orang tua memegang peranan penting dalam membentuk sikap dan perilaku remaja (Brofenbrenner dalam Puspitawati 2006). Studi ini akan mencoba fokus memahami migrasi pemuda di desa dari perspektif sosialisasi nilai pertanian melalui agen sosialisasi primer. Berangkat dari latar belakang di atas maka penelitian ini maka penelitian ini akan fokus dalam menjawab beberapa pertanyaan penelitian, antara lain adalah: (1) Bagaimana komunikasi ritual 


\section{Commed : Jurnal Komunikasi dan Media Vol. 4 No. 2 Februari 2020}

ISSN. 2527-8673

E-ISSN. 2615.6725

dalam bentuk perayaan sedekah bumi sebagai upaya pewarisan nilai pertanian kepada pemuda di Desa Ciasmara, Kecamatan Pamijahan, Kabupaten Bogor? (2) Bagaimana tingkat partisipasi pemuda dalam terlibat dalam membantu orang tua dalam kegiatan mengolah tanah dan panen padi di Desa Ciasmara, Kecamatan Pamijahan Kabupaten Bogor? (3) Apakah terdapat hubungan antara tingkat partisipasi Pemuda di sektor pertanian dengan Tingkat Kognitif dan Afektif Pemuda terhadap Pekerjaan di Sektor Pertanian?

Berdasarkan latarbelakang di atas maka, penelitian ini bertujuan untuk: (1) Mengidentifikasi komunikasi ritual dalam bentuk perayaan sedekah bumi sebagai upaya pewarisan nilai pertanian kepada pemuda. (2) Mengidentifikasi tingkat partisipasi pemuda dalam terlibat dalam membantu orang tua dalam kegiatan mengolah tanah dan panen padi di Desa Ciasmara, Kecamatan Pamijahan Kabupaten Bogor. (4) Menganalisis hubungan antara tingkat partisipasi Pemuda di sektor pertanian dengan Tingkat Kognitif dan Afektif Pemuda terhadap Pekerjaan di Sektor Pertanian.

\section{METODOLOGI PENELITIAN}

\section{Sistem Ekologi Manusia}

Konsep Ekologi manusia menyangkut saling ketergantungan antara manusia dengan lingkungannya, baik sumberdaya alam maupun sumberdaya buatan. Pendekatan ekologi atau ekosistem menyangkut

hubungan interdependensi antara manusia dan lingkungan di sekitarnya sesuai dengan aturan norma kultural yang dianut. Konsep ekologi manusia juga dikaitkan dengan pembangunan. Keberhasilan pembangunan yang berkelanjutan sangat bergantung pada faktor manusianya, yaitu seluruh penduduk dan sumberdaya alam yang dimiliki serta penguasaan ilmu pengetahuan dan teknologi. Kaidah ekologi menetapkan adanya ketahanan atau ketegaran (resilience) suatu sistem yang dipengaruhi oleh dukungan yang serasi dari seluruh subsistem (Soerjani dalam Puspitawati, 2009).

Mengingat manusia adalah mahluk sosial yang menyangkut hubungan antar pribadi dan hubungan antar manusia dengan lingkungannya di sekitarnya, maka manusia tidak dapat berdiri sendiri. Manusia akan sangat bergantung pada lingkungan sekitarnya (baik lingkungan mikro meso, dan makro). Brofenbrenner (1981) dalam Puspitawati (2009) menyajikan model ekologi manusia untuk mengerti proses sosialisasi yang diterima oleh anak. Pada model tersebut dijelaskan bahwa lingkungan Mikrosistem merupakan lingkungan terdekat dengan seorang individu, meliputi keluarga, sekolah, teman sebaya, dan tetangga. Lingkungan yang lebih luas lagi disebut lingkungan mesosistem, dan akhirnya lingkungan yang paling jauh dari individu disebut dengan makrosistem. Sementara itu, Menurut Nugraha (2012); Nugraha dan Herawati (2015); Valdiani et. al (2017), orang tua memegang peranan penting dalam 
membangun nilai - nilai pertanian bagi anak anak mereka baik nilai yang sifatnya positif maupun yang nilainya negatif. Bentuk pewarisan nilai yang sifatnya positif biasanya dalam bentuk pelibatan anak dalam membantu orang tuanya ketika melihat ritual perayaan hasil pertanian. Sementara itu pewarisan nilai negatif biasanya dalam bentuk diskusi dalam keluarga mengenai kegagalan panen, hama yang menyerang, padi dibeli dengan harga murah.

\section{Ritual dan Pewarisan Nilai}

Menurut Turner dan West (2006) dalam Nugraha dan Supriatna (2020), terdapat 3 (tiga) bentuk ritual yang sangat mempengaruhi peneliti, yaitu: Selebrasi, Tradisi, dan Interaksi yang terpola. Selebrasi merupakan ritual yang dilakukan secara luas diseluruh budaya, contohnya liburan Thanksgiving, Hari kemerdekaan, upacara seremonial seperti pernikahan, dan pemakaman. Meskipun acaraacara tersebut merupakan suatu acara yang dilakukan oleh seluruh orang, tetapi setiap keluarga memiliki cara-cara unik dalam menyelenggarakan acara tersebut. Tradisi merupakan ritual yang lebih aneh lagi untuk setiap keluarganya dan tidak dilakukan oleh masyarakat luas, artinya hanya spesifik dalam suatu keluarga, contoh dari tradisi adalah liburan keluarga, reuni (arisan) keluarga, ulang tahun. Sementara itu interaksi keluarga yang terpolakan (patterned family interaction) merupakan ritual yang biasa yang tidak direncanakan, dan paling sering dilakukan oleh keluarga, contohnya seperti makan malam, dongeng tengah malam, dan biasanya interaksi keluarga yang terpola merupakan aktivitas yang dilakukan bersama-sama yang membangun dan menjaga identitas suatu keluarga. Turner dan West (2006) dalam Nugraha dan Supriatna (2020), mengatakan interaksi keluarga yang terpola sering sulit dibedakan dengan kegiatan rutin dalam keluarga karena kedua hal tersebut merupakan kegiatan-kegiatan yang biasa dilakukan dalam keluarga, tetapi perbedaannya adalah dalam interaksi keluarga yang terpola terdapat makna-makna simbolik dimana terdapat suatu kegiatan penghormatan akan sesuatu yang sedang dipertaruhkan. Menurut Nugraha (2012); Nugraha dan Supriatna (2020); Di beberapa wilayah pertanian padi di Jawa, Ritual dalam pertanian bisa terdiri dari beberapa aktivitas antara lain melibatkan anak laki - laki membantu orang tua mereka dalam proses panen atau pengolahan lahan sementara itu anak perempuan dalam dilibatkan dalam proses tanam ataupun proses panen atau sebatas mengantarkan makanan bersama ibu mereka. Selain itu terdapat lagi ritual pertanian yang berkaitan dengan perayaan seperti seren taun maupun sedekah bumi.

\section{Desain Penelitian}

Penelitian ini menggunakan metode kuantitatif dengan pendekatan deskriptif korelasional. Pendekatan deskriptif pada 
penelitian ini diharapkan dapat memunculkan gambaran mengenai jenis ritual pemuda di pedesaan, tingkat partisipasi pemuda dalam terlibat membantu orang tua mereka, dan tingkat kognisi dan afeksi pemuda terhadap pekerjaan di sektor pertanian. Sementara itu pendekatan korelasional hendak melihat hubungan antara tingkat pelibatan pemuda dalam membantu orang tua dengan tingkat kognitif dan afektif pemuda terhadap pekerjaan di sektor pertanian.

Lokasi, Waktu Penelitian, Sampel, dan Pengumpulan data

Desa Ciasmara, Kecamatan Pamijahan, Kabupaten Bogor dipilih secara purposif, melalui beberapa pertimbangan antara lain: (1) Merupakan sentra pertanian padi di Kabupaten Bogor (Kab Bogor dalam Angka 2018) dan (2) secara lokasi desa Ciasmara terletak di antara dua wilayah yang saling tarik menarik tenaga kerja, satu wilayah industri garmen dan wilayah dan dua wilayah pertanian. Kondisi ini memunculkan relasi baru dimana garmen - garmen di sekitar desa Ciasmara banyak mempekerjakan tenaga kerja muda yang berasal dari desa Ciasmara (Nugraha dan Nugroho, 2018), sehingga faktor penarik (Pull - Factor) dari luar desa dapat mempengaruhi ketertarikan atau ketidaktertarikan pemuda untuk bekerja di sektor pertanian di desa Ciasmara. Studi ini telah dilaksanakan sejak bulan Februari 2019 sampai dengan Juli 2019, sebanyak 129 pemuda berusia 15 sd 24 tahun dan belum menikah terpilih sebagai sampel penelitian dengan teknik purposif sampling. Karena penelitian ini menggunakan metoda campuran konkuren (Mixed Method Concurrent), maka selain orangtua, terdapat juga sebanyak 60 orang tua petani dijadikan sebagai responden pembanding informasi dari pemuda.

Teknik Analisis Data dan Pengumpulan Data

Pada dasarnya penelitian ini menggunakan Metoda Campuran Konkuren, yaitu penggunaan metode kuantitatif dan kualitatif secara bersamaan untuk saling memvalidasi jawaban dari setiap item pertanyaan terhadap responden dan informan. Data diperoleh menggunakan instrumen penelitian (kuesioner) yang diberikan kepada pemuda di desa Ciasmara dan pandun wawancara digunakan sebagai panduan dalam mewawancarai orang tua pemuda

\section{Analisis Deskriptif dan Inferensia}

Analisis deskriptif yang digunakan dalam penelitian ini berupa tabulasi deskriptif yang berisi frekuensi, persentase, dan rataan skor dari tingkat partisipasi pemuda dalam membantu orang tua dalam tahapan panen, tingkat partisipasi pemuda dalam membantu orang tua dalam tahapan tanam, tingkat kognitif pemuda desa Ciasmara terhadap pekerjaan di sektor 
pertanian padi dan tingkat afeksi pemuda terhadap pekerjaan di sektor pertanian padi. Analisis inferensia yang akan digunakan dalam penelitian ini adalah uji korelasi rank spearman. Uji korelasi digunakan untuk melihat secara parsial sejauhmana Tingkat keterlibatan pemuda dalam kegiatan panen dan tanam memiliki hubungan dengan tingkat kognitif dan tingkat afeksi pemuda di desa Ciasmara Kecamatan Pamijahan Kabupaten Bogor.

\section{Definisi Operasional}

Dalam penelitian ini terdapat 3 variabel utama, yaitu Ritual Perayaan Pertanian (X1), Tingkat Pelibatan Pemuda dalam Membantu Orang Tua (X2), dan Kognisi dan Afeksi terhadap Pekerjaan di Sektor Pertanian (Y). Ritual perayaan pertanian (X1) dalam penelitian ini didefinisikan sebagai pelaksanaan perayaan sedekah bumi di Desa Ciasmara, sehingga akan terlihat apakah keluarga tersebut melaksanakan perayaan sedekah bumi atau tidak. Tingkat Pelibatan Pemuda dalam Membantu Orang Tua (X2) dalam penelitian ini didefinisikan sebagai tingkat keseringan pemuda dalam membantu orang tua mereka ketika pengolahan lahan dan panen pertanian padi. Tingkat Kognitif (Y1.1) dalam penelitian ini didefinisikan sebagai tingkat pengetahuan pemuda terkait praktik-praktik pertanian dan Tingkat Afeksi (Y1.2) dalam penelitian ini didefinisikan sebagai ketertarikan atau ketidaktarikan pemuda terhadap pekerjaan di sektor pertanian.

\section{HASIL DAN PEMBAHASAN}

\section{Konteks Pertanian Desa Ciasmara}

Di desa Ciasmara terdapat satu Gapoktan bernama Asmara jaya yang di dalamnya terdapat delapan kelompok tani besar. Pak Maji (Ketua Gapokta Asmara Jaya) mengatakan petani di desa Ciasmara sudah terkategorikan petani modern tetapi mereka belum benar - benar memanfaatkan teknologi pertanian secara optimal. Petani masih mempertahankan sistem pertanian yang diwariskan oleh orangtua mereka seperti jarak tanam yang digunakan, sistem jejer legowo yang diintroduksikan jarang digunakan, petani cenderung menggunakan Caplak (Kayu) untuk membuat baris tanam. Dalam menentukan masa tanam, petanipetani di desa Ciasmara masih membuka ruang diskusi antara petani muda dengan petani sepuh di kantor desa Ciasmara. Terdapat tiga petani sepuh yang sering dimintai pendapatnya, antara lain: Pak Rohman, H. Soleh, H Ija. Varietas padi yang digunakan juga sudah variates baru, hanya petani - petani di wilayah Cibereum yang masih menggunakan benih- benih lokal, produktivitasnya juga tinggi bisa mencapai 5 -6 Ton/ Ha.

Petani - petani yang kadang tidak seragam dalam menanam adalah petani sewa 


\section{Commed : Jurnal Komunikasi dan Media Vol. 4 No. 2 Februari 2020}

ISSN. 2527-8673

E-ISSN. 2615.6725

karena mereka harus memanfaatkan lahan.

Pak Junaedi (Kepala Desa) mengakui bahwa tradisi secara bersama sudah mulai hilang, namun tradisi masih tetap ada tapi masih atau hanya di tingkat petani lokal. Pak Maji mengatakan bahwa sistem tradisional ketika panen mejadi hilang karena tengkulak langsung membeli padi di sawah petani, sehingga padi milik petani tidak sampai ke rumah petani. Pak Kades menambahkan bahwa sebenarnya desa yang masih kuat tradisi pertaniannya adalah desa muara dekat desa Cibunian, di sana kepala desa masih mempraktikan sedekah bumi. Menurut penuturan Kepala Desa, di Desa Ciasmara sebenarnya masih terdapat tradisi sukuran ketika panen tetapi bentuknya hanya makan bersama di kantor desa. Selain tradisi saat panen. Selain itu petani juga tidak boleh sembarangan memanen padi karena ada posisi - posisi dan waktu - waktu tertentu yang dianjurkan, seperti yang diutarakan oleh pak Kepala Desa, dirinya memanen pada hari Sabtu karena beliau menanam juga di hari sabtu. Sabtu sangat disakralkan oleh Pak Kepala Desa karena hari sabtu adalah hari kelahiran kepala desa. Pak Maji mengakui bahwa tradisi menanam juga masih ada, misalnya harus menghadap arah mana, kondisi seperti ini membuat pak Maji menyerahkan penanaman terhadap ibu-ibu tua yang sudah memiliki pengalaman menentukan arah.

\section{Gambaran Sistem Pertanian Desa Ciasmara}

Sistem panen yang digunakan di Desa Ciasmara merupakan sistem panen Gedeng, artinya satu karung berisi 100 liter Beras. (atau sekitar $60 \mathrm{Kg}$ ). Sistem panen di desa Ciasmara masih menggunakan sistem Gebot, teknologi power thrasher sempat masuk tetapi tidak laku karena mayorita tenaga kerja panen adalah wanita sementara itu power thrasher itu harus diangkut dan berat medannya karena pertimbangan tersebut teknologi tersebut tidak laku. Pak Maji mengakui bahwa sistem panen di Desa Ciasmara terbilang lama dan rumit, karena tengkulak tidak bisa langsung membawa gabah kering panen. Para buruh tani biasanya membersihkan dulu dari gabah - gabah yang kosong atau kering sehingga butuh waktu untuk proses pembersihan ini. Selain proses pembersihan ini, proses lain yang juga menyita waktu adalah proses memasukan literan beras kedalam karung, satu karung kira - kira 10 liter beras. Sistem pengupahan buruh panen juga beragam, ada buruh panen yang meminta bayaran harian ada juga yang berdasarkan biaya per gedeng, biasanya berkisar 2000 sd 2500 per gedeng. Jumlah buruh panen terbatas di desa ciasmara, kondisi ini menyebabkan buruh tani memiliki posisi tawar yang baik, artinya buruh panen bisa menentukan sistem pengupahan apa yang mereka inginkan. Pak Maji menambahkan bahwa buruh panen juga 
memiliki strategi (pintar), biasanya jika musim hujan mereka memilih upah harian sekitar 25 sd 30 ribu dari jam 08 sd 12, kondisi hujan membuat banyak buruh panen bisa bersantai karena jika hujan turun maka buruh panen bisa bersantai dan baru melanjutkan ketika hujan berhenti. Sementara itu jika musim kemarau mereka memilih sistem pembayaran per gedeng. Tugas buruh panen dari mulai menyabit, menggebot sampai memasukkan gabah ke dalam karung. Komoditas utama pertanian yang diusahakan oleh para petani di Desa Ciasmara adalah tanaman tanaman pangan padi. Meskipun padi sebagai komoditas utama, tetapi dimasa reses (istirahat) lahan, petani juga menanam komoditas lain seperti tanaman palawija dan tanaman hortikultura seperti talas, ketimun, kacang panjang, dan cabai merah. Teknik penanaman yang dilakukan cenderung monokultur (satu tanaman), jikapun petani menerapkan sistem tanam tumpang sari, maka tumpang sari tersebut tetap mengutamakan padi sebagai tanaman utama dengan kombinasi ketimun ataupun tanaman talas.

\section{Ritual Sedekah Bumi dalam Keluarga Sebagai Upaya Pewarisan Nilai - Nilai Pertanian}

Penelitian ini menemukan bahwa di beberapa dusun di desa Ciasmara masih terdapat tradisi perayaan Sedekah Bumi. Pada dasarnya sedekah bumi merupakan sebuah aktivitas bersyukur atas hasil bumi yang diperoleh petani setelah panen. Secara terminologis, Sedekah Bumi adalah perayaan dalam rangka memanjatkan syukur kepada Tuhan YME atas segala kemudahan dalam proses bertaninya.

Tabel 1. Sebaran Responden Berdasarkan Perayaan Sedekah Bumi

\begin{tabular}{cc}
\hline Sedekah Bumi & Persen $(\boldsymbol{\%})$ \\
\hline Merayakan & 89 \\
Tidak & 11 \\
\hline Total & $\mathbf{1 0 0}$ \\
\hline
\end{tabular}

Dari fokus dua kampung penelitian, Kampung Kebon Alas dan Kampung Jogjogan Ilir, sebanyak 89 persen petani di kedua kampung tersebut masih merayakan sedekah bumi dan sebesar 11 persen petani tidak merayakan sedekah bumi. Petani di desa Ciasmara mengatakan bahwa perayaan sedekah bumi saat ini sering dilaksanakan di mesjid atau mushala berbarengan dengan membaca tahlil dan yasinan. Sementara itu petani yang tidak merayakan sedekah bumi mengatakan perayaan sedekah bumi tersebut tidak ada dalam anjuran agama dan warga di sekitar lingkungannya juga sudah tidak merayakanya

Pada penelitian ini, petani - petani yang bertempat tinggal Kampung Kebon Alas Desa Ciasmara masih mempraktikan Sedekah Bumi. Praktik Sedekah Bumi di Desa Ciasmara berlangsung pada saat tahun baru Islam dan disesuaikan pada saat petani setelah panen. Bentuk perayaanya biasanya 
dilakukan di dalam Mushala dengan membaca puji - pujian kepada Kanjeng Nabi Muhammad SAW. Dahulu ritual ini lebih dikenal dengan istilah Seren Taun, tetapi berubah menjadi Sedekah Bumi agar lebih dekat dengan diksi keislaman. Sedekah bumi di desa Ciasmara bukan merupakan kegiatan yang diinisiasi penuh oleh pemerintahan tetapi masih merupakan inisiasi bersama warga desa Ciasmara ketika memasuki tahun baru Islam atau ketika bulan pertama Hijriah. Praktik sedekah bumi di desa Ciasmara sudah mengalami transformasi tata cara tanpa merubah esensi, seperti yang diutarakan oleh salah seorang petani, Abin (40):

“... Sekarang perayaan sdekah bumi tidak seperti dulu, karena sudah terdapat warga yang meninggalkan tradisi itu, tetapi kami [Warga Kebon Alas] masih melakukan sedekah bumi biasanya setiap $R W$ mengadakan kegiatan sedekah bumi di mesjid mereka masing - masing”

Para petani di Kampung Kebon Alas memaknai perayaan sedekah bumi sebagai proses bersyukur kepada tuhan dan sebagai pewarisan nilai pertanian $\mathrm{k}$ kepada generasi berikutnya. Perayaan sedekah bumi tidak hanya diikuti oleh orang tua saja tetapi diikuti oleh pemuda, anak kecil, dan perempuan yang berada di Kampung Kebon Alas desa Ciasmara. Perayaan Ritual Sedekah Bumi di desa Ciasmara dilakukan di dalam mushala masing - masing kampung, dengan cara mengadakan tahlilan disertai dengan membuat bubur merah, bubur putih, serta menyediakan kopi pahit dan kopi manis, telur, terasi, jeruk, gula jawa, pisang, pepaya, cabai bakar dan bawang bakar, biskuit dan jeruk atau yang biasa disebut dengan "rujakeun". Selain menyediakan “rujakeun" petani juga membaca doa tahlil berupa yasin serta puji - pujian berbahasa Sunda. Terdapat pula petani yang menggunakan Shalawat Pasuruan serta Manakib dengan meyebut nama Abdul Khadir Jaelani dalam doanya (lih. Gambar 1).

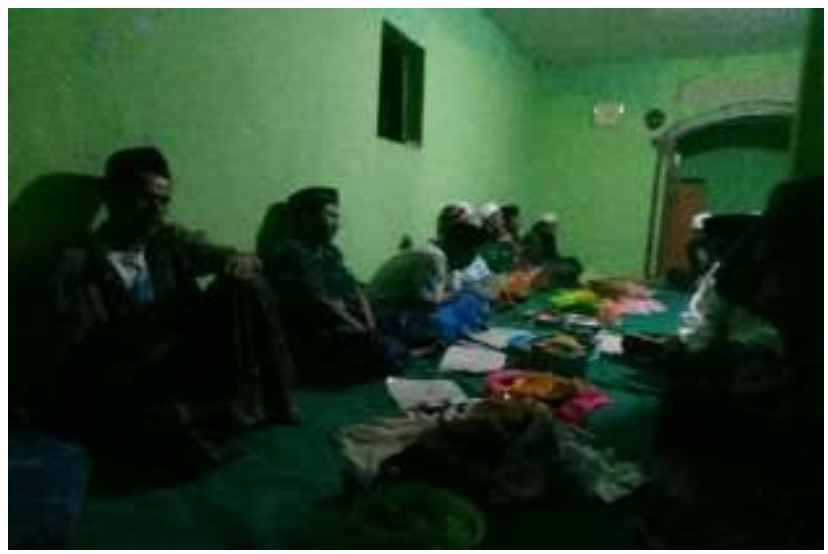

Gambar 1. Foto Perayaan Sedekah Bumi di Kebon Alas Desa Ciasmara (Foto: Wahyudi)

Pelibatan Anak dalam Membantu Orang Tua Sebagai Pewarisan Pengetahuan dan Afeksi Pertanian.

Proses pewarisan nilai - nilai pertanian terjadi secara alami dalam keluarga, demikian pula dengan pewarisan nilai - nilai pertanian dari orangtua kepada anak. Baik disadari maupun tidak disadari proses pewarisan tersebut terjadi. Proses 
pewarisan tersebut terjadi dalam pola yang berbeda - beda di antara keluarga. Nugraha (2012); Nugraha dan Herawati (2015) mengutarakan bahwa pola pewarisan nilai pertanian bisa dalam berbagai bentuk antara lain adalah tingkat pelibatan pemuda dalam membantu orang tua bertani.

\section{Ritual Pelibatan Pemuda dalam}

Membantu Orang Tua Mengolah Tanah.

Ritual keterlibatan pemuda dalam membantu orang tua dalam penelitian ini didefinisikan sebagai frekuensi pemuda dalam membantu orang tua mereka dalam kegiatan mengolah tanah dan panen.

Tabel 1. Tingkat Partisipasi Pemuda Membantu Orang Tua Mengolah Lahan

\begin{tabular}{ccc}
\hline $\begin{array}{c}\text { Terlibat } \\
\text { Mengolah Tanah }\end{array}$ & $\begin{array}{c}\text { Persen } \\
(\boldsymbol{\%})\end{array}$ & $\begin{array}{c}\text { Rataan } \\
\text { Skor }\end{array}$ \\
\hline Sangat Rendah & 36.43 & \\
Rendah & 27.91 & $\mathbf{2 . 0 6}$ \\
Tinggi & 28.68 & \\
Sangat Tinggi & 6.98 & \\
\hline Total & $\mathbf{1 0 0 . 0 0}$ & \\
\hline
\end{tabular}

Ket: 1 - 1.75: Sangat Rendah; $1.76-2.51$ : Rendah; 2.52 - 3.27: Tinggi; 3.28 - 4: Sangat Tinggi.

Tabel 1 menunjukan bahwa sebagian besar pemuda (36.43\%) di desa Ciasmara memiliki tingkat partisipasi yang sangat rendah dalam membantu orang tua mereka dalam kegiatan mengolah tanah. Sementara itu, sekitar 28.68 persen pemuda di desa Ciasmara masih terlibat dalam membantu orang tua mereka dalam mengolah sawah sebelum mulai tanam. Sangat rendahnya frekuensi partisipasi pemuda dalam membantu orang tua mereka mengolah lahan disebabkan oleh beberapa faktor antara lain adalah: (1) Sekolah, pemuda di desa Ciasmara memiliki keterbatasan waktu untuk bisa terlibat membantu orang tua mereka mengolah lahan. Pada umumnya kegiatan mengolah lahan dilakukan pagi hari sampai pukul 12. Pada waktu - waktu tersebut pemuda di desa Ciasmara tengah mengikuti kegiatan belajar - mengajar di sekolah mereka. (2) Tidak langsung mendapatkan bayaran, pemuda mengakui tidak begitu tertarik membantu orang tua mereka mengolah tanah karena tidak mendapatkan bayaran langsung dari orang tua mereka, hal ini berbeda dengan kegiatan panen di mana pemuda langsung mendapatkan bayaran seusai membantu orang tua mereka panen. (3) Penggunaan Traktor, alasan lain yang menyebabkan pemuda di desa Ciasmara sudah tidak berpartisipasi dalam kegiatan membantu orang tua mereka dalam mengolah tanah adalah kemunculan traktor dalam pengolahan tanah. Para petani di desa Ciasmara saat ini sudah menggunakan traktor karena dianggap lebih cepat dan lebih murah jika dibandingkan dengan menggunakan kerbau, selain itu populasi kerbau di desa Ciasmara juga relatif tidak sebanyak dulu.

\section{Ritual Pelibatan Pemuda dalam Membantu Orang Tua pada Kegiatan Panen}

Selain ritual pelibatan dalam kegiatan pengolahan lahan, riset ini juga melihat ritual 
pelibatan pemuda di desa dalam membantu orang tua pada kegiatan panen.

Tabel 2. Sebaran Resonden Berdasarkan Tingkat Partisipasi Pemuda dalam Membantu Orangtua pada Kegiatan Panen.

\begin{tabular}{ccc}
\hline $\begin{array}{c}\text { Membantu } \\
\text { Panen }\end{array}$ & $\begin{array}{c}\text { Persen } \\
(\boldsymbol{\%})\end{array}$ & $\begin{array}{c}\text { Rataan } \\
\text { Skor }\end{array}$ \\
\hline Sangat Rendah & 24.03 & \\
Rendah & 22.48 & $\mathbf{2 . 5 2}$ \\
Sering & 37.21 & \\
Sangat Sering & 16.28 & \\
\hline Total & $\mathbf{1 0 0 . 0 0}$ & \\
\hline
\end{tabular}

Ket: 1 - 1.75: Rendah ; 1.76 - 2.51: Rendah; 2.52 - 3.27: Sering; 3.28 - 4: Sangat Sering.

Penelitian ini menemukan bahwa terdapat perbedaan dalam hal ritual pelibatan pemuda dalam kegiatan mengolah tanah dan kegiatan panen. Secara keseluruhan pada Tabel 2 dapat dilihat bahwa pemuda di desa Ciasmara masih sering terlibat dan dilibatkan dalam membantu orang tua mereka dalam kegiatan panen. Sementara itu jika dilihat secara lebih mendetail, lebih dari 53 persen pemuda di desa Ciasmara sering terlibat dalam membantu orang tua mereka dalam kegiatan panen dan sekitar 47 persen. Pemuda di Desa Ciasmara sering membantu orang tua mereka dalam kegiatan panen karena pemuda membantu orang tua mereka akan dihitung sebagai buruh panen, setiap buruh panen yang mengerjakan satu gendeng sawah (sekitar 1500M²) bayarannya adalah satu $10 \mathrm{~kg}$ gabah. Hal ini menjadi alasan utama kenapa pemuda masih ikut terlibat membantu orang tua mereka dalam kegiatan panen. Selain itu, orang tua juga cenderung melibatkan anak mereka dalam kegiatan panen dalam rangka menurunkan biaya produksi panen. Orang tua pun merasa senang saat anak mereka membantu panen di sawah mereka sendiri karena dapat menghemat pengeluaran dan mengganti uang saku anak menjadi upah anak di sawah. Hal seperti ini juga ditemukan dalam riset Nugraha (2012); Nugraha dan Herawati (2015), konsep pemuda membantu orang tua dalam proses panen dalam rangka menurunkan biaya produksi (family labour).

\section{Hubungan Antara Ritual Pelibatan Orang Tua dengan Tingkat Kognitif dan Afeksi Pemuda.}

Menurut Nugraha (2012); Nugraha dan Herawati (2015); dan Nugraha dan Nugroho (2019). Pewarisan nilai yang dilakukan oleh orang tua dapat diukur melalui melalui dua dimensi, yaitu: ritual orang tua dalam melibatkan anak mereka dalam kegiatan mengolah tanah dan pelibatan dalam panen padi. Kedua kegiatan ini dipilih karena merupakan kegiatan yang paling sering melibatkan pemuda.

\section{Tabel 3. Hubungan Antara Ritual Pelibatan Orang Tua dengan Tingkat Kognitif dan Afeksi Pemuda.}

\begin{tabular}{ccc}
\hline Ritual & Kognitif \\
Pelibatan Orang Tua & $\begin{array}{c}\text { Afeksi } \\
\text { Pemuda }\end{array}$ \\
\hline $\begin{array}{c}\text { Pelibatan dalam } \\
\text { Pengolahan Lahan } \\
\text { Pelibatan dalam } \\
\text { Panen Padi }\end{array}$ & 0.170 & $0.396^{* *}$ \\
\hline Ket: ** Sangat Signifikan & $0.387^{* *}$ \\
\hline
\end{tabular}

Ket: ** Sangat Signifikan 


\section{Commed : Jurnal Komunikasi dan Media Vol. 4 No. 2 Februari 2020}

Dari Tabel 3 dapat dilihat bahwa ritual pelibatan pemuda dalam kegiatan panen padi memiliki hubungan yang sangat signifikan dan cukup kuat dengan tingkat pengetahuan dan tingkat dengan arah hubungan positif, 0.260 dan 0.387 . Hal ini mengindikasikan bahwa tingkat pelibatan pemuda dalam kegiatan panen dapat meningkatkan pengetahuan pemuda tentang pertanian dan meningkatkan afeksi pemuda terhadap bidang pertanian. Sementara itu untuk pelibatan dalam kegiatan pengolahan sawah hanya berhubungan sangat signifikan dan cukup kuat dengan tingkat afeksi pemuda. Hal ini berarti bahwa semakin tinggi tingkat pelibatan pemuda dalam kegiatan mengolah tanah maka tingkat afeksi pemuda terkait bidang pertanian juga akan semakin tinggi.

Pelibatan pemuda dalam kegiatan pertanian memiliki beberapa fungsi, baik manfaat langsung maupun tidak langsung. Manfaat langsung dalam melibatkan pemuda adalah menekan biaya produksi, seperti yang utarakan oleh Nugraha dan Herawati (2015) yang mengatakan keterlibatan pemuda dalam tahapan pertanian mampu mengurangi biaya produksi total hal ini dikenal dengan istilah family labour. Namun, paradoks yang tengah terjadi dewasa ini adalah introduksi teknologi pertanian yang semakin masif justru menghilangkan keterlibatan pemuda dalam kegiatan pertanian.

\section{PENUTUP}

Simpulan dari penelitian ini adalah:

1. Sedekah bumi masih dirayakan di desa Ciasmara Kecamatan Pamijahan Kabupaten Bogor. Namun proses pelaksanaan sedekah bumi tersebut sudah mengalami transformasi dengan digabungkan dengan perayaan hari besar kegamaan.

2. Pemuda di desa Ciasmara masih terlibat membantu orang tua mereka dalam kegiatan pengolahan lahan pertanian mereka dan panen padi. Hal ini karena kedua kegiatan tersebut dianggap sebagai titik dimana pemuda dapat memperoleh uang tambahan untuk jajan.

3. Pelibatan dalam kegiatan panen dapat meningkatkan pengetahuan dan afeksi pemuda desa Ciasmara terhadap pertanian padi, sementara pelibatan dalam kegiatan mengolah lahan hanya mampu meningkatkan afeksi pemuda terhadap pertanian padi.

\section{Saran}

1. Pemerintah desa Ciasmara harus mampu memanfaatkan tanah kemakmuran desa atau tanah tidak bertuan di desa untuk kepentingan pemuda desa agar pemuda desa dapat mengenal kegiatan pertanian sejak dini. 
2. Pertanian dimasukkan ke dalam ekstrakulikuler di tingkat SD, SLTP, dan SLTA yang berada di desa Ciasmara terutama dengan fokus pada kegiatan pengolahan tanah dan penen padi.

3. Mengatur introduksi teknologi pertanian padi terutama teknologi panen agar disesuaikan dengan konteks desa dan tidak menggantikan tenaga kerja pemuda pada kegiatan panen.

\section{DAFTAR PUSTAKA}

Badan Pusat Statistik. (2017). Indikator Ekonomi. In Buletin Statistik Bulanan (Issue November). https://doi.org/10.11607/ijp.3688

Nugraha, YA. 2012. Hubungan Orang Tua, Media Massa, dan Teman dengan Sikap Pemuda terhadap Pekerjaan di Bidang Pertanian (Kasus Pemuda di Desa Cipendawa dan Desa Sukatani, Kecamatan Pacet, Kabupaten Cianjur). [Tesis]. IPB. Bogor

Nugraha, YA dan R, Herawati. 2015.

Menguak Realitas Orang Muda Pertanian di Pedesaan. Jurnal Analisis Sosial: Vol 19 No 1. Akatiga: Bandung.

Nugraha, YA dan Siregar MRS. 2018. The Role of Local Loan Institution in Providing Safety Net in Rural Area. Journal of Humanities and Social Studies. 2 (1).

Nugraha, YA dan Nugroho DR. 2019. Rural Youth Behavior in Watching Television (Case Study Rural Youth in Ciasmara Village). Journal of Humanities and Social Studies. 3 (1).
Nugraha, Y., \& Supriatna, R. (2020). Peran Teman Sepermainan dalam Membentuk Sikap Pemuda Pedesaan terhadap Pekerjaan di Sektor Pertanian Padi (Kasus Pemuda di Desa Ciasmara, Kecamatan Pamijahan Kabupaten Bogor). JIA (Jurnal Ilmiah Agribisnis) : Jurnal Agribisnis dan Ilmu Sosial Ekonomi Pertanian, 5(1).

Puspitawati, H. 2006. Pengaruh Faktor Keluarga, Lingkungan Teman, dan Sekolah terhadap Kenakalan Pelajar di Sekolah Lanjutan Tingkat Atas di Kota Bogor. [disertasi]. Bogor: Sekolah Pascasarjana, Institut. Pertanian Bogor. Bogor.

H, 2009. Kenakalan Remaja di Pengaruhi oleh Sistem Sekolah dan Keluarga. IPB Press. Bogor.

Valdiani D, Nugraha YA, dan Siregar MRS. 2017. Attendance of Mass Media and Parents in Defining The Value of Agriculture in Rural Youth. Journal of Humanities and Social Studies. $1(1)$. 